\title{
PARTIAL CHARACTERIZATION OF A NEW BULL SPERM ARYLAMIDASE
}

\author{
STANLEY MEIZEL AND JOSEPH GOTHAM \\ Department of Human Anatomy, School of Medicine, University of California, \\ Davis, California 95616 U.S.A.
}

(Received 27th August 1971, accepted 20th September 1971)

Enzymes which hydrolyse the amide linkage of aminoacyl napthylamides, are generally called arylamidases, napthylamidases or arylaminopeptidases. Such enzymes are found in many tissues and organisms and may exhibit specificity for certain acidic, basic and/or neutral amino acid- $\beta$-naphthylamides. Some arylamidases are exopeptidases or endopeptidases. The present report describes the partial characterization of a new bull sperm arylamidase which exhibited a greater relative rate of hydrolysis with L-methionyl- $\beta$-naphthylamide than with ten other amino acid naphthylamides. Preliminary aspects of this work were briefly reported elsewhere (Meizel \& Cotham, 1971).

Assays of enzymatic activity during and after purification of the enzyme were based on the spectrofluorometric detection of the $\beta$-naphthylamine released during enzymatic hydrolysis of the amino acid naphthylamide substrates (Greenberg, 1962). A Hitachi-Perkin-Elmer MPF-2A spectrofluorometer was utilized for these assays which were carried out at $25^{\circ} \mathrm{C}$ with an excitation wavelength of $330 \mathrm{~m} \mu$ and an emission wavelength of $405 \mathrm{~m} \mu$. An incomplete assay solution consisting of $3.4 \mathrm{ml} 0.05 \mathrm{M}-\mathrm{NaH}_{2} \mathrm{PO}_{4}-\mathrm{Na}_{2} \mathrm{HPO}_{4}, \mathrm{pH} 8$ (or other appropriate buffer with or without inhibitor), $0.05 \mathrm{ml} 71 \mathrm{~mm}$-dithiothreitol and $0.05 \mathrm{ml}$ enzyme solution were incubated at $25^{\circ} \mathrm{C}$ for $15 \mathrm{~min}(30$ min for inhibitor studies). After preincubation, $0.05 \mathrm{ml} 71 \mathrm{mM}-$ or $7.1 \mathrm{mM}-\mathrm{L}-$ methionyl- $\beta$-naphthlamide or other amino acid naphthylamide substrate (Schwartz/Mann Company) dissolved in dimethylformamide were added to complete the assay solution. Assays were carried out with amounts of enzyme which produced linear rate responses and never consumed more than $0.3 \%$ of the substrate. Standard curves were used to determine rates of hydrolysis and corrections for acid pH quenching (McDonald, Zeitman, Reilly \& Ellis, 1969).

Semen was collected by electrical ejaculation from two Jersey bulls. The spermatozoa were washed in order to remove seminal plasma and free cytoplasmic droplets (Allison \& Hartree, 1970). Washed spermatozoa (10 g wet weight) were frozen and thawed twice in $4 \mathrm{ml}$ of a $1 \%$ aqueous solution of hyamine 2389 (Rohm and Haas Company). The homogenate was centrifuged at $50,000 \mathrm{~g}$ for $30 \mathrm{~min}$ at $0^{\circ} \mathrm{C}$. The $50,000 \mathrm{~g}$ supernatant was brought to $50 \%$ ammonium sulphate saturation at $0^{\circ} \mathrm{C}$ and centrifuged as described above. The resulting supernatant was brought to $70 \%$ ammonium sulphate saturation at $0^{\circ} \mathrm{C}$ and, after centrifugation, a precipitate was obtained which was redissolved 


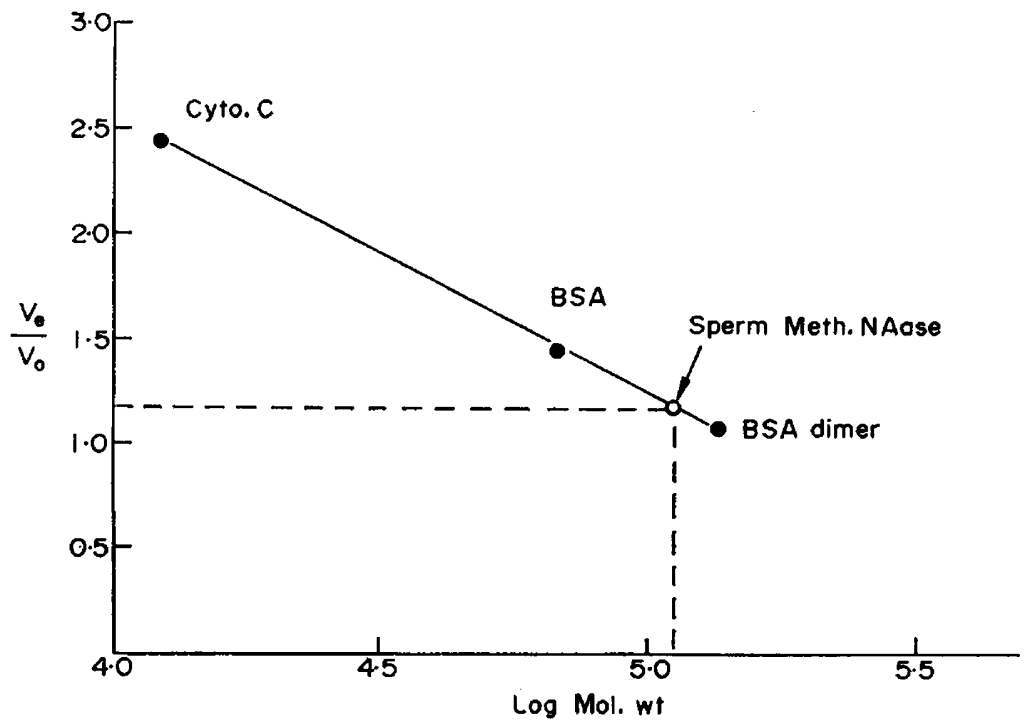

Text-FIG. 1. Estimation of the molecular weight of the sperm arylamidase by gel filtration on a Sephadex G-100 column. Protein standards: bovine serum albumin monomer and dimer (mol.wt 67,000 and 134,000, respectively) and horse cytochrome $c$ (mol.wt $12,400)$. The ratio of each protein's elution volume to the column's void volume is represented by $\mathrm{V}_{\mathrm{e}} / \mathrm{V}_{\mathrm{n}}$.

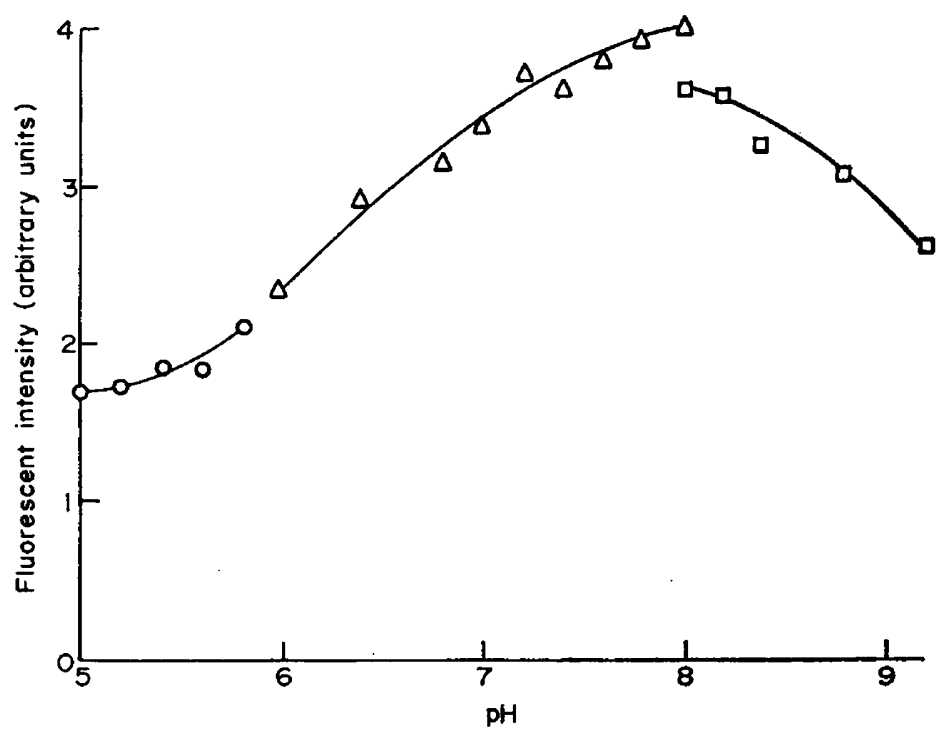

TexT-FIG. 2. Effect of pH on the hydrolysis of L-methionyl- $\beta$-naphthylamide by the sperm arylamidase preparation obtained by Sephadex G-100 column chromatography. Buffers: $0.05 \mathrm{M}$-sodium acetate-acetic acid (O), 0.05 $\mathrm{M}-\mathrm{NaH}_{2} \mathrm{PO}_{4}-\mathrm{Na}_{2} \mathrm{HPO}_{4}(\triangle)$, and $0.05 \mathrm{M}$-tris- $\mathrm{HCl}(\square)$. Increased substrate hydrolysis is represented by increased fluorescent intensity. 
in $1 \mathrm{ml} 50 \mathrm{~mm}$-tris- $\mathrm{HCl}$ buffer, $\mathrm{pH} 7.0$ containing $1 \mathrm{~mm}$-dithiothreitol. The redissolved precipitate was applied to a $1.5 \times 80 \mathrm{~cm}$ Sephadex G-100 column, and the L-methionyl- $\beta$-naphthylamidase (Meth.NAase) activity was eluted in $1.5-\mathrm{ml}$ fractions at $4^{\circ} \mathrm{C}$ with the tris buffer containing dithiothreitol. A single

TABLE 1

HYDROLYSIS OF VARIOUS AMINO AGID- $\beta$-NAPHTHYLAMIDES BY THE SPERM ARYLAMIDASE PREPARATION OBTAINED BY SEPHADEX G-100 COLUMN GHROMATOGRAPHY

\begin{tabular}{l|c}
\hline \multicolumn{1}{c|}{ B-Naphthylamide* } & Relative rate of hydrolysis (\%) \\
\hline L-Methionine & 100 \\
L-Isoleucine & 40 \\
L-Leucine & 20 \\
L-Valine & 20 \\
L-Phenylalanine & 10 \\
L- $\alpha$-Aspartic acid & 5 \\
L-Alanine & 0 \\
L-Arginine & 0 \\
L-Lysine & 0 \\
L-Proline & 0 \\
$\alpha$-Benzoyl-DL-arginine $\dagger$ & 0 \\
\hline
\end{tabular}

* Substrate concentration was $0.1 \mathrm{~mm}$ for these assays.

$\dagger$ Substrate for sperm trypsin-like enzymes (Ho \& Meizel, 1970).

TABLE 2

THE EFFEGT OF VARIOUS COMPOUNDS ON THE ENZYMATIC ACTIVITY OF THE SPERM ARYLAMIDASE PREPARATION OBTAINED BY SEPHADEX G-100 COLUMN GHROMATOGRAPHY*

\begin{tabular}{l|c}
\hline \multicolumn{1}{c|}{ Compound } & $\begin{array}{c}\text { Percentage of } \\
\text { control activity }\end{array}$ \\
\hline Dithiothreitol (1 mM) & 2300 \\
Ethylene diaminetetraacetic acid (1 mM) & 100 \\
l,10-Phenanthroline $(0 \cdot 1 \mathrm{~mm})$ & 50 \\
N- $\alpha$-p-Tosyl-L-lysine chloromethyl & 65 \\
ketone HCl $(0 \cdot 05 \mathrm{~mm})$ & 100 \\
N-Tosyl-L-phenylalanine chloromethyl & \\
ketonet (0.05 mM) & 0 \\
Diisopropyl fluorophosphate (1 mM) & \\
\hline
\end{tabular}

* All assays were performed with $\mathrm{L}$-methionyl- $\beta$-naphthylamide $(1 \mathrm{mM})$ as the substrate.

$\dagger$ Preincubation and assay were carried out at pH 6, as recommended by Schoellman \& Shaw (1963).

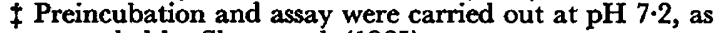
recommended by Shaw et al. (1965).

Meth.NAase peak was eluted with a specific activity of $0 \cdot 191$ international units/mg protein (protein content was assayed by the method of Bramhall, Noack, Wu \& Loewenberg, 1969). This specific activity represented a sevenfold purification over the crude homogenate. Sephadex G-100 chromatography was used (Whitaker, 1963) to calculate an apparent molecular weight of 112,000 
for the sperm Meth.NAase (Text-fig. 1). The $\mathrm{pH}$ optimum of the enzyme after chromatography was 8 (Text-fig. 2).

Relative substrate specificity of the sevenfold purified enzyme was tested with eleven acidic, basic and neutral amino acid- $\beta$-naphthylamides. The highest rate of hydrolysis was observed with L-methionyl- $\beta$-naphthylamide but there was hydrolysis of several other naphthylamides (Table 1). Studies were also made of the effects of several potential inhibitors and activators (Sigma Chemical Company) on the hydrolysis of L-methionyl- $\beta$-naphthylamide by the sevenfold purified enzyme (Table 2). The thiol reagent, dithiothreitol, greatly activated the enzyme, but the chelating agent, phenanthroline, and the serine phosphorylating agent, diisopropyl fluorophosphate, were inhibitory to the Meth. NAase. Ethylenediaminetetraacetic acid, a weaker chelating agent than phenanthroline, was not inhibitory. $\mathrm{N}-\alpha-\mathrm{p}-$ Tosyl-L-lysine chloromethyl ketone HCl (TLCK) but not N-tosyl-L-phenylalanine chloromethyl ketone (TPCK) inhibited Meth.NAse activity. Both ketones inhibit enzymes by alkylation of imidazole groups of particular histidyl residues (Schoellmann \& Shaw, 1963; Shaw, Mares-Guia \& Cohen, 1965), or by alkylation of active sulphhydryl groups (Whitaker \& Perez-Villasenor, 1968). It is interesting to note that TLCK inhibits fertilization in rabbits, presumably by inhibiting the trypsinlike enzyme of rabbit spermatozoa (Zaneveld, Robertson \& Williams, 1970).

Hydrolysis of the $\beta$-naphthylamides of L-isoleucine, L-leucine, L-valine and L-phenylalanine (Table 1) was activated by dithiothreitol and inhibited by diisopropyl fluorophosphate and phenanthroline to approximately the same extent as that of L-methionyl- $\beta$-naphthylamide. (The effect of TLCK on the hydrolysis of these substrates was not tested.) The results suggest that the same enzyme was responsible for the hydrolysis of all these substrates. However, hydrolysis of $\mathrm{L}-\alpha$-aspartic acid- $\beta$-naphthylamide was not inhibited or activated and must have been due to a different enzyme.

Other bull semen constituents were also assayed for Meth.NAase activity. Bull cytoplasmic droplets shed from spermatozoa during epididymal maturation were isolated and homogenized as previously described (Dott \& Dingle, 1968; Meizel, Boggs \& Cotham, 1971). The sperm Meth.NAase was not detected in droplet homogenates. The specific activity of the enzyme in bull seminal plasma centrifuged free of particulate matter was 150 times lower than that of the crude sperm homogenate, and may have been due to leakage from the spermatozoa. We have also detected a dithiothreitol activated hydrolysis of L-methionyl- $\beta$-naphthylamide with a $\mathrm{pH}$ optimum of 8 in preliminary experiments with homogenates of rabbit spermatozoa.

Arylamidases exhibiting higher rates of hydrolysis with L-methionyl- $\beta$ naphthylamide than with other amino acid- $\beta$-naphthylamides have been detected in rat blood leucocytes and rat wound tissue (Makinen \& Rackallio, 1968) rat testis (Vanha-Perttula, 1971) and calf brain ribosomes (Kerwar, Weissbach \& Glenner, 1971). These arylamidases appear to differ from the bull sperm Meth.NAase in one or more properties such as $\mathrm{pH}$ optimum and molecular weight. The biological function of this new sperm arylamidase is not known. 
This research was primarily supported by NIH Grant No. HDO3549 to one of us (S.M.). Partial support was also provided by NIH General Research Support Grant No. RR05684. Extensive use was made of the equipment and facilities of Health Sciences Advancement Award USPHS No. RR06138.

\section{REFERENCES}

Allison, A. G. \& Hartree, E. F. (1970) Lysomal enzymes in the acrosome and their possible rôle in fertilization. 7. Reprod. Fert. 21, 501.

Bramhall, S., Noack, N., Wu, M. \& Loewenberg, J. R. (1969) A simple colorimetric method for the determination of protein. Analyt. Biochem. 31, 146.

DotT, H. M. \& Dingle, J. T. (1968) Distribution of lysosomal enzymes in the spermatozoa and cytoplasmic droplets of bull and ram. Expl Cell Res. 52, 523.

GreenberG, L. J. (1962) Fluorometric measurement of alkaline phosphatase and aminopeptidase activities in the order of $10^{-14}$ mole. Biochem. biophys. Res. Comm. 9, 430.

Ho, J. L. \& MEIZEL, S. (1970) Electrophoretic detection of multiple forms of trypsin-like activity in spermatozoa of the domestic fowl. F. Reprod. Fert. 23, 177.

Kerwar, S. S., Weissbach, H. \& GlenNer, G. G. (1971) An aminopeptidase activity associated with brain ribosomes. Archs Biochem. Biophys. 143, 336.

McDonald, J. K., Zeitman, B. B., Reilly, T. J. \& Ellis, S. (1969) New observations on the substrate specificity of cathepsin C (Dipeptidyl aminopeptidase I). 7. biol. Chem. 244, 2693.

Mäkinen, P. L. \& Raekallio, J. (1968) Purification and properties of an arylaminopeptidase of rat wound tissue acting chiefly on the $\beta$-naphthylamides of L-methionine and L-valine. Acta chem. scand. 22, 3111.

Meizel, S., Boggs, D. \& Cotham, J. (1971) Electrophoretic studies of esterases of bull spermatozoa, cytoplasmic droplets and seminal plasma. F. Histochem. Cytochem. 19, 226.

Meizel, S. \& Cotham, J. (1971) Characterization of a new bull spermatozoan amino acid naphthylamidase. (Abstract). Fedn Proc. Fedn Am. Socs. exp. Biol. 1298.

Schoellmann, G. \& Shaw, E. (1963) Direct evidence for the presence of histidine in the active center of chymotrypsin. Biochemistry, Easton, Pa. 2, 252.

Shaw, E., Mares-Gula, M. \& Cohen, W. (1965) Evidence for an active center histidine in trypsin through use of a specific reagent, 1-chloro-3-tosylamido-7-amino-2-heptanone, the chloromethyl ketone derived from N- $\alpha$-tosyl-L-lysine. Biochemistry, Easton, Pa. 4, 2219.

Vanka-Pertulua, T. (1971) Aminopeptidases of rat testis in experimental conditions. Scand. $\mathcal{f}$. clin. Lab. Invest. 27, Suppl. 116, 9.

Whitaker, J. R. (1963) Determination of molecular weights of proteins by gel filtration on Sephadex. Analyt. Chem. 35, 1950.

Whitaker, J. R. \& Perez-Villasenor, J. (1968) Chemical modification of papain reaction with the chloromethyl ketones of phenylalanine and lysine and with phenylmethylsulfenyl fluoride. Archs Biochem. Biophys. 124, 70.

Zaneveld, L. J. D., Robertson, R. T. \& Williams, W. L. (1970) Synthetic enzyme inhibitors as antifertility agents. FEBS Letters, 11, 345. 